\title{
KARAKTERISTIK MAKANAN RINGAN EKSTRUDAT DARI KEPALA UDANG VANNAMEI (Litopenaeus vannameI)
}

\section{Characteristics of Extruded Snacks Food with the Addition of Vannamei Shrimp Head (Litopenaeus vannamei)}

\author{
Suryanti ${ }^{1 *}$, Sakinah Haryati ${ }^{2}$, Achmad Noerkhaerin Putra ${ }^{2}$ dan Rafika Heryana ${ }^{2}$ \\ ${ }^{1}$ Balai Besar Riset Pengolahan Produk dan Bioteknologi Kelautan dan Perikanan, \\ JI. KS Tubun Petamburan VI, Slipi, Jakarta, Indonesia \\ ${ }^{2}$ Fakultas Pertanian, Jurusan Perikanan, Universitas Sultan Ageng Tirtayasa, \\ Jalan Raya Jakarta Km 4, Kota Serang, Banten \\ *Korespondensi Penulis: suryanti_jkt@yahoo.com
}

Diterima: 21 November 2017; Direvisi: 22 Januari 2018; Disetujui: 4 Juni 2018

\begin{abstract}
ABSTRAK
Pengembangan penelitian produk makanan ringan ekstrudat dari kepala udang vannamei (Litopenaeus vannamei) telah dilakukan. Penelitian ini bertujuan untuk mengetahui karakteristik makanan ringan ekstrudat yang dihasilkan dengan penambahan kepala udang vannamei. Proses pembuatan makanan ringan ekstrudat terdiri dari persiapan bahan baku (pembuatan grit kepala udang, jagung dan beras) dan formulasi dengan tiga perlakuan konsentrasi kepala udang vannamei yaitu $0 \%$ (kontrol), $5 \%$ dan $10 \%$. Proses pembuatan makanan ringan ekstrudat dilakukan menggunakan alat ekstruder berulir tunggal pada suhu $\pm 160{ }^{\circ} \mathrm{C}$. Parameter pengamatan yang dilakukan terhadap produk makanan ringan ekstrudat yang dihasilkan meliputi analisis proksimat, mikrobiologi (ALT dan E. coli), tekstur kekerasan, derajat putih, aktivitas air $\left(\mathrm{a}_{\mathrm{w}}\right)$, dan sensori. Hasil penelitian menunjukkan perlakuan 5\% kepala udang vannamei memenuhi persyaratan makanan ringan ekstrudat berdasarkan SNI 2886:2015 dengan kandungan protein 11,55\% (bb), lemak 0,83\% (bb) ALT 7,1 $\times 10^{3}$ koloni/g dan E.coli negatif. Nilai tekstur kekerasan 324,13 g dalam waktu 10,67 detik, derajat putih $47,57 \%$ dan $a_{w} 0,7$. Selain itu, hasil uji sensori menunjukkan perlakuan $5 \%$ kepala udang vannamei menghasilkan aroma dan rasa mendekati spesifik bau udang serta tekstur yang renyah.
\end{abstract}

KATA KUNCI: makanan ringan, ekstrudat, Litopenaeus vannamei, kepala udang

\section{ABSTRACT}

Research on the development of extruded snacks food products with the addition of vannamei shrimp (Litopenaeus vannamei) head has been conducted. This study aimed to determine the characteristics of extruded snacks food produced by the addition of vannamei shrimp head. The process of making extruded snacks consisted of preparation of raw material (preparation grits from vannamei shrimp head, corn and rice) and formulation with three treatments of vannamei shrimp head with concentration $0 \%$ (control), $5 \%$ and $10 \%$. The process of making extruded snacks used a single screw extruder device at a temperature of $\pm 160^{\circ} \mathrm{C}$. The observed parameters of extruded snacks products of proximate, microbiology (TPC and E. coli), hardness, whiteness, water activity $\left(a_{w}\right)$, and sensory. The result showed that the concentration of vannamei shrimp head of $5 \%$ was met extruded snacks requirements according to SNI 2886:2015 with protein content of $11.55 \%$ (bb), fat $0.83 \%$, TPC values of $7.1 \times 10^{3}$ colonies $/ g$ and negative E. coli. Hardness value was $324.13 \mathrm{~g}$ in 10.67 second, whiteness $47.57 \%$ and $\mathrm{a}_{\mathrm{w}} 0.7$. In addition, the result of sensory test showed that $5 \%$ of vannamei shrimp head treatment produced crispy texture and specific odor and taste.

KEYWORDS: snacks food, extrudate, Litopenaeus vannamei, shrimp head

\section{PENDAHULUAN}

Udang vannamei (Litopenaeus vannamei) merupakan salah satu komoditas ekspor perikanan yang umumnya diekspor dalam kondisi udang segar beku tanpa kepala (frozen headless shrimp). Dari industri proses pengolahan produk udang tersebut banyak dihasilkan limbah yang meliputi kepala dan kulit dengan jumlah berkisar antara 35-45\% dari berat udang utuh (Cao, Tan, Zhan, Li, \& Zhang, 2014), yang hingga saat ini limbah tersebut sebagian besar masih diolah menjadi pakan ternak. Pada umumnya limbah 
udang yang berasal dari industri pembekuan udang masih mengandung protein yang cukup besar yaitu 31,58\% (Sudarman, Laksmiastuti, \& Sumiati, 2014) sehingga dapat dijadikan sebagai alternatif sumber protein untuk produk pangan. Salah satu upaya untuk meningkatkan pemanfaatan limbah kepala udang dapat dilakukan dengan diversifikasi pengolahan produk perikanan dengan tujuan untuk meningkatkan nilai gizi protein dan sebagai penguat flavor atau aroma udang pada produk pangan.

Makanan ringan ekstrudat merupakan salah satu jenis makanan ringan yang banyak disukai konsumen. Makanan ringan ekstrudat adalah makanan ringan siap makan yang dibuat dari bahan pangan sumber karbohidrat dan atau protein melalui proses ekstrusi dengan atau tanpa penambahan bahan pangan lain dan bahan tambahan pangan yang diizinkan dengan atau tanpa melalui proses penggorengan (BSN, 2015). Teknologi proses pengolahan pangan dengan ekstrusi sangat baik digunakan untuk memperoleh produk makanan ringan yang siap untuk dimakan. Selama proses pemasakan ekstrusi digunakan bahan baku pati dan protein dengan kandungan air rendah (maksimal $30 \%$ ) yang menggunakan kombinasi perlakuan suhu tinggi $\left( \pm 120^{\circ} \mathrm{C}\right)$ dan tekanan tinggi yang dapat menyebabkan terjadinya pergeseran mekanis serta menimbulkan perubahan struktur dan berbagai reaksi molekul yang dapat mengubah sifat fisiko kimia dan fungsional bahan (Saeleaw, Dürrschmid, \& Schleining, 2012).

Dalam proses pengolahan pangan dengan proses ekstrusi, bahan baku harus dalam bentuk bulir, grit dan / atau bubuk atau tepung (BSN, 2015) dan kondisi kering. Grit adalah butiran kecil dengan ukuran lebih besar dari tepung tetapi masih lebih kecil dari ukuran butiran aslinya. Ukuran butiran yang besar akan menyulitkan proses perpindahan panas dan perpindahan massa di dalam bahan yang diolah (Fellow, 2000). Bahan baku pangan yang dapat menghasilkan sifat plastis akan terdesak masuk ke dalam proses pemasakan ekstrusi melalui sebuah lubang 'die' yang menyebabkan suhu dan tekanan menurun sepanjang die dan menghasilkan perubahan sifat bahan dengan cepat (Maskan \& Altan, 2012). Salah satu karakteristik utama produk makanan ringan ekstrudat adalah mikrostruktur tekstur yang dapat diketahui dari kekerasan dan kerenyahan melalui pengujian fisik secara mekanis dan sensori.

Pada umumnya, produk makanan ringan ekstrudat mengandung pati yang tinggi dari jagung, beras, gandum dan sumber pati lainnya. Pati beras lebih banyak digunakan dalam proses ekstrusi karena kandungan air rendah, berwarna putih, rasa netral dan mudah dicerna (Xie et al., 2009) dan memiliki karakteristik ukuran granula pati kecil sesuai dengan proses ekstrusi (Suarni \& Widowati, 2016). Selain pati beras, bahan baku pati jagung dapat menghasilkan produk ekstrudat yang mudah mengembang dan menghasilkan tekstur yang renyah dengan flavor rasa jagung yang khas (Matz, 1997). Namun demikian, pati jagung dan beras memiliki kandungan nilai gizi protein yang rendah, sehingga perlu dilakukan usaha diversifikasi produk makanan ringan ekstrudat untuk meningkatkan kandungan protein. Makanan ringan ekstrudat dapat ditingkatkan kandungan nilai gizi proteinnya dari sumber protein nabati seperti protein kedele (Yu et al., 2013) dan protein hewani seperti tepung udang (Parapenaeopsis stylifera) (Shaviklo, Azaribeh, Moradi, \& Zangeneh, 2015) dan tepung protein ikan dari surimi ikan saithe (Pollachius virens) (Shaviklo, Olafsdottir, Sveinsdottir, Thorkelsson, \& Rafipour, 2011) yang dapat menghasilkan perubahan tekstur produk. Selama proses pemasakan ekstrusi, struktur molekul protein mengalami perubahan yang menyebabkan terjadinya agregasi, koagulasi dan denaturasi hingga dapat membentuk suatu ikatan silang dengan molekul pati yang berpengaruh pada mikrostruktur dan tekstur produk esktrudat (Day \& Swanson, 2013).

Dalam penelitian ini dilakukan upaya diversifikasi produk perikanan berupa makanan ringan ekstrudat dengan penambahan limbah kepala udang vannamei (Litopenaeus vannamel) sebagai sumber gizi protein dan flavor atau aroma udang. Penelitian ini bertujuan untuk mengetahui karakteristik makanan ringan ekstrudat yang dihasilkan dari kepala udang vannamei (Litopenaeus vannamei). Selain itu, penelitian ini juga bertujuan untuk meningkatkan pemanfaatan limbah kepala udang agar tidak merusak lingkungan dan mendukung ketahanan pangan nasional melalui usaha diversifikasi produk pangan yang bernilai gizi protein tinggi pada makanan ringan ekstrudat.

\section{BAHAN DAN METODE}

\section{Bahan dan Alat}

Bahan utama yang digunakan dalam pembuatan makanan ringan ekstrudat (snack) terdiri dari beras (Oryza sativa), jagung (Zea mays), limbah kepala udang vannamei (Lithopenaeus vannamei) segar dari industri pengolahan udang segar beku di Kabupaten Subang, Jawa Barat, garam serta bahan-bahan kimia yang digunakan dalam analisis kimia dan mikrobiologi.

Peralatan yang digunakan dalam pembuatan makanan ringan ekstrudat (snack) adalah alat ekstruder berulir tunggal, grinder, thermometer, alat penghancur biji-bijian (hammer mill), timbangan 
Tabel 1. Formulasi makanan ringan ekstrudat")

Table 1. Formulation of extruded snacks*)

\begin{tabular}{lccc}
\hline \multicolumn{1}{c}{ Sampel/Sample } & Konsentrasi /Consentration (\%) \\
\cline { 2 - 4 } & Jagung/Corn & Beras/Rice & $\begin{array}{c}\text { Kepala udang vannamei/ } \\
\text { Vannamei shrimp head }\end{array}$ \\
\hline $\begin{array}{l}\text { Makanan ringan ekstrudat } \\
\text { kontrol/Extruded snacks control } \\
\text { Makanan ringan ekstrudat 1/ }\end{array}$ & 70 & 30 & 0 \\
$\begin{array}{l}\text { Extruded snacks 1 } \\
\text { Makanan ringan ekstrudat 2/ } \\
\text { Extruded snacks 2 }\end{array}$ & 70 & 25 & 5 \\
\hline
\end{tabular}

Keterangan/Note : "Subagja (2009) yang sudah dimodifikasi/Modified from Subagja (2009)

digital, oven, TA-XT plus texture analyzer, whiteness meter, $a_{w}$ meter, lembar uji sensori serta peralatan lain yang digunakan dalam analisis kimia dan mikrobiologi.

\section{Metode}

Penelitian ini diawali dengan persiapan bahan utama yaitu limbah kepala udang, jagung dan beras. Limbah kepala udang vannamei (Lithopenaeus vannamei) segar, jagung dan beras dicuci dan dikeringkan dengan oven pada suhu berkisar antara $60-70{ }^{\circ} \mathrm{C}$ hingga kering. Proses dilanjutkan dengan penggilingan hingga diperoleh grit kepala udang vannamei, jagung dan beras.

Pembuatan makanan ringan ekstrudat (extruded snacks) diawali dengan pencampuran grit kepala udang vannamei, jagung dan beras kering secara manual hingga merata dengan formulasi bahan seperti terlihat pada Tabel 1. Bahan yang telah tercampur rata kemudian dimasukkan ke dalam alat ekstruder yang selanjutnya akan mengalami proses ekstrusi pada suhu $\pm 160^{\circ} \mathrm{C}$ hingga menghasilkan makanan ringan ekstrudat setelah waktu proses pemasakan ekstrusi berjalan selama 3-5 menit. Makanan ringan ekstrudat yang dihasilkan kemudian dikemas dalam plastik agar terhindar dari kerusakan fisik dan kimia.

Parameter pengamatan yang dilakukan terhadap makanan ringan ekstrudat yang diperoleh meliputi analisis proksimat, sensori, tekstur kekerasan, warna (derajat putih), aktivitas air $\left(a_{w}\right)$ dan mikrobiologi. Analisis proksimat meliputi kadar air, kadar abu, kadar protein dan kadar lemak yang dilakukan berdasarkan SNI 01.2354-2006 (BSN, 2006). Analisis sensori menggunakan uji mutu hedonik berdasarkan SNI 23462011 (BSN, 2011) oleh panelis semi terlatih dari laboratorium sensori Balai Besar Riset Pengolahan Produk dan Bioteknologi Kelautan dan Perikanan sebanyak 15 orang. Analisis fisik terhadap sifat tekstur kekerasan (Saeleaw, et al., 2012) dan analisis warna berdasarkan nilai derajat putih (Suryaningrum, Ikasari,
Supriyadi, Mulya \& Purnomo, 2016). Analisis aktivitas air $\left(a_{w}\right)$ dilakukan menggunakan alat $\mathrm{a}_{\mathrm{w}}$ meter TH 500 Novasina (Suryaningrum, 2016). Analisis mikrobiologi meliputi ALT berdasarkan SNI 01-2332.3-2006 (BSN, 2006) dan E. coli berdasarkan SNI 01-2332.1-2006 (BSN, 2006). Rancangan percobaan yang digunakan adalah Rancangan Acak Lengkap dengan 3 kali ulangan. Hasil data analisa yang diperoleh kemudian diolah menggunakan SPSS (statistical package for social science) Version 17 dengan uji lanjut Duncan.

\section{HASIL DAN PEMBAHASAN}

\section{Komposisi Proksimat}

Bahan baku makanan ringan ekstrudat umumnya berasal dari pati jagung dan beras, sehingga perlu penambahan bahan makanan lain sebagai sumber protein untuk meningkatkan nilai gizi makanan ringan ekstrudat seperti kepala udang vannamei (Lithopenaeus vannameI). Dalam penelitian ini, bahan baku yang digunakan dalam pengolahan makanan ringan ekstrudat meliputi grit jagung, beras dan kepala udang vannamei (Lithopenaeus vannameI) dengan komposisi proksimat yang dapat dilihat pada Tabel 2. Pada tabel ini diketahui bahwa kandungan protein jagung dan beras sangat rendah yaitu $11,16 \%$ dan $8,28 \%$ sedangkan kandungan protein kepala udang vannamei sangat tinggi yaitu $40,87 \%$.

Peningkatan nilai gizi protein yang dihasilkan pada makanan ringan ekstrudat dapat dilihat melalui komposisi proksimat pada Tabel 3. Tabel 3 menunjukkan kandungan protein makanan ringan ekstrudat dengan penambahan kepala udang vanamei $5 \%$ dan $10 \%$ sebesar $11,48 \%$ dan $11,67 \%$ lebih besar daripada kontrol $9,95 \%$ dan makanan ringan ekstrudat dengan penambahan tepung ikan sebesar $10,77 \%$ (Octavia, 2007). Kandungan air dan abu makanan ringan ekstrudat dengan penambahan kepala udang vannamei juga lebih besar daripada kontrol, sedangkan kandungan lemak dan karbohidrat lebih rendah 
Tabel 2. Komposisi proksimat bahan baku makanan ringan ekstrudat Table 2. Proximate composition of extruded snacks raw material

\begin{tabular}{cccccc}
\hline \multirow{2}{*}{$\begin{array}{c}\text { Bahan baku/ } \\
\text { Raw material }\end{array}$} & \multicolumn{2}{c}{ Komposisi proksimat (\%) b/b/Proximate composition (\%) w/w } \\
\cline { 2 - 5 } & $\begin{array}{c}\text { Mir/ } \\
\text { Moisture }\end{array}$ & $\begin{array}{c}\text { Abu/ } \\
\text { Ash }\end{array}$ & $\begin{array}{c}\text { Protein/ } \\
\text { Protein }\end{array}$ & $\begin{array}{c}\text { Lemak/ } \\
\text { Fat }\end{array}$ & $\begin{array}{c}\text { Karbohidrat/ } \\
\text { Carbohidrate }\end{array}$ \\
\hline Jagung/Corn & $10.31 \pm 0.02^{\mathrm{a}}$ & $1.21 \pm 0.02^{\mathrm{a}}$ & $11.16 \pm 0.16^{\mathrm{a}}$ & $0.00^{\mathrm{a}}$ & $77.17 \pm 0.08^{\mathrm{a}}$ \\
Beras/Rice & $11.26 \pm 0.13^{\mathrm{a}}$ & $0.44 \pm 0.13^{\mathrm{b}}$ & $8.28 \pm 0.78^{\mathrm{b}}$ & $0.00^{\mathrm{a}}$ & $79.60 \pm 1.02^{\mathrm{a}}$ \\
$\begin{array}{c}\text { Kepala udang vannamei/ } \\
\text { Vannamei shrimp head }\end{array}$ & $6.49 \pm 0.40^{\mathrm{b}}$ & $33.79 \pm 0.40^{\mathrm{c}}$ & $40.87 \pm 0.33^{\mathrm{c}}$ & $7.83 \pm 0.08^{\mathrm{c}}$ & $10.51 \pm 1.04^{\mathrm{b}}$ \\
\hline
\end{tabular}

Keterangan/Note :

Hasil merupakan nilai rata-rata tiga kali ulangan/The result are average of three replicates

Huruf yang sama pada kolom yang sama menunjukkan tidak berbeda nyata/The same letters in the same column indicate no significant difference

walaupun tidak terdapat perbedaan yang nyata $(p>0,05)$.

Kadar air makanan ringan ekstrudat merupakan salah satu parameter utama dalam menentukan kualitas. Batas maksimal kadar air pada makanan ringan ekstrudat berdasarkan SNI 2886-2015 adalah 4\%. Kadar air pada makanan ringan ekstrudat dengan penambahan kepala udang vannamei dan kontrol sedikit lebih besar dari persyaratan makanan ringan ekstrudat yaitu 5,82\% dan 5,63\%. Bahan baku dengan kandungan protein tinggi yang digunakan selama proses pemasakan ekstrusi akan lebih banyak mengikat molekul air dan terperangkap dalam struktur matrik molekul protein-pati sehingga kandungan air menjadi lebih besar. Makanan ringan ekstrudat dengan penambahan kepala udang vannamei juga memiliki kandungan lemak yang relatif rendah yaitu $0,83 \%$ dan $0,84 \%$. Batas maksimal kadar lemak yang disyaratkan oleh SNI yaitu 30\% (tidak melalui proses penggorengan), dan 38\% (melalui penggorengan). Kandungan lemak dapat mempercepat terjadinya oksidasi lemak sehingga menghasilkan flavor tengik pada produk tinggi. Kandungan lemak makanan ringan ekstrudat dengan panambahan kepala udang vannamei $5 \%$ dan $10 \%$ memenuhi persyaratan makanan ringan ekstrudat menurut SNI yaitu $0,83 \%$ dan $0,84 \%$. Selain itu, umumnya kepala udang mengandung mineral yang cukup banyak seperti yang dinyatakan Coward-Kelly, Agbogbo, dan Holtzapple (2006) bahwa kandungan mineral dalam kepala udang Penaeus indicus di antaranya fosfor sebesar 1,27\%, kalium $1,05 \%$ dan kalsium 4,63\%. Hal ini menyebabkan kandungan abu makanan ringan ekstrudat dengan penambahan kepala udang vannamei $5 \%$ dan $10 \%$ lebih besar daripada kontrol $(0,86 \%)$ yaitu $1,55 \%$ dan $1,50 \%$.

\section{Sensori}

Hasil analisis sensori dari uji hedonik terhadap parameter mutu aroma, rasa, tekstur dan kenampakan dapat dilihat pada Gambar 1. Dari Gambar 1 diketahui bahwa aroma dan rasa makanan ringan ekstrudat

Tabel 3. Komposisi proksimat makanan ringan ekstrudat

Table 3. Proximate composition of extruded snacks

\begin{tabular}{cccccc}
\hline $\begin{array}{c}\text { Konsentrasi kepala udang } \\
\text { vannamei (\%)/ }\end{array}$ & \multicolumn{3}{c}{ Komposisi proksimat (\%) b/b/Proximate composition (\%) w/w } \\
\cline { 2 - 6 } $\begin{array}{c}\text { Consentration of vannamei } \\
\text { shrimp head (\%) }\end{array}$ & $\begin{array}{c}\text { Air/ } \\
\text { Moisture }\end{array}$ & $\begin{array}{c}\text { Abu/ } \\
\text { Ash }\end{array}$ & $\begin{array}{c}\text { Protein/ } \\
\text { Protein }\end{array}$ & $\begin{array}{c}\text { Lemak/ } \\
\text { Fat }\end{array}$ & $\begin{array}{c}\text { Karbohidrat/ } \\
\text { Carbohidrate }\end{array}$ \\
\hline 0 & $4.76 \pm 0.13^{\mathrm{a}}$ & $0.86 \pm 0.01^{\mathrm{a}}$ & $9.95 \pm 0.06^{\mathrm{a}}$ & $0.78 \pm 0.06^{\mathrm{a}}$ & $82.59 \pm 0.41^{\mathrm{a}}$ \\
5 & $5.82 \pm 0.17^{\mathrm{a}}$ & $1.55 \pm 0.07^{\mathrm{a}}$ & $11.48 \pm 0.08^{\mathrm{a}}$ & $0.83 \pm 0.12^{\mathrm{a}}$ & $80.33 \pm 0.12^{\mathrm{a}}$ \\
10 & $5.63 \pm 0.16^{\mathrm{a}}$ & $1.50 \pm 0.05^{\mathrm{a}}$ & $11.67 \pm 0.04^{\mathrm{a}}$ & $0.84 \pm 0.27^{\mathrm{a}}$ & $80.36 \pm 0.58^{\mathrm{a}}$ \\
\hline
\end{tabular}

Keterangan/Note :

Hasil merupakan nilai rata-rata tiga kali ulangan/The result are average of three replicates

Huruf yang sama pada kolom yang sama menunjukkan tidak berbeda nyata/The same letters in the same column indicate no significant difference 
dengan penambahan kepala udang vannamei $5 \%$ memiliki nilai tertinggi daripada konsentrasi $10 \%$ dan kontrol, sedangkan tekstur dan kenampakan sampel kontrol memiliki nilai tertinggi. Hal ini menunjukkan penggunaan kepala udang vannamei pada konsentrasi yang makin besar akan makin menurunkan penilaian sensori pada parameter mutu aroma, rasa, tekstur dan kenampakan makanan ringan ekstrudat yang dihasilkan.

Bahan baku utama makanan ringan ekstrudat yaitu beras dan jagung memiliki kandungan amilosa sekitar 20-30\% (Suarni \& Widowati, 2016; Kim, Jane, \& Lamsal, 2017). Proses pemasakan ekstrusi dengan bahan baku pati yang mengandung amilosa tinggi lebih sulit dilakukan karena memiliki suhu pelelehan dan viskositas yang lebih tinggi sehingga membutuhkan tekanan yang lebih besar dalam 'die'. Amilosa merupakan salah satu komponen utama pati yang memiliki molekul linear polisakarida dengan ikatan $\alpha$ 1,4 yang lebih mudah berikatan hidrogen dengan molekul lain (Xie et al., 2009). Penggunaan protein dalam konsentrasi yang besar dapat menyebabkan pengaruhnya makin besar pada proses degradasi pati selama proses pemasakan ekstrusi. Selama proses pemasakan ekstrusi terjadi gelatinisasi pati, di mana molekul pati akan berikatan dengan molekul air hingga terbentuk swell (mengembang) dan menghasilkan viskositas yang tinggi. Setelah melewati 'die', molekul pati yang telah tergelatinisasi akan berubah menjadi jernih transparan atau glassy state, kemudian mengembang pada suhu yang menurun hingga terbentuk struktur tekstur yang mengeras (Fellow, 2000).

Kandungan protein yang tinggi dalam bahan baku makanan ringan ekstrudat dapat mempengaruhi pengikatan molekul air oleh molekul pati karena protein memiliki gugus molekul yang bersifat hidrofilik dan bermuatan ion sehingga dapat larut dalam air. Kondisi ini menyebabkan molekul pati sulit untuk mengembang dan menghasilkan tekstur produk makanan ringan ekstrudat yang cenderung bertekstur keras.

Hasil uji hedonik kenampakan makanan ringan ekstrudat (Gambar 1) dengan penambahan kepala udang vannamei pada konsentrasi $10 \%$ makin menurun karena warna yang makin gelap seperti terlihat pada Gambar 2. Hal ini disebabkan karena adanya reaksi Maillard yang terjadi selama proses pemasakan ekstrusi. Konsentrasi protein yang besar dalam proses pemasakan ekstrusi sangat besar

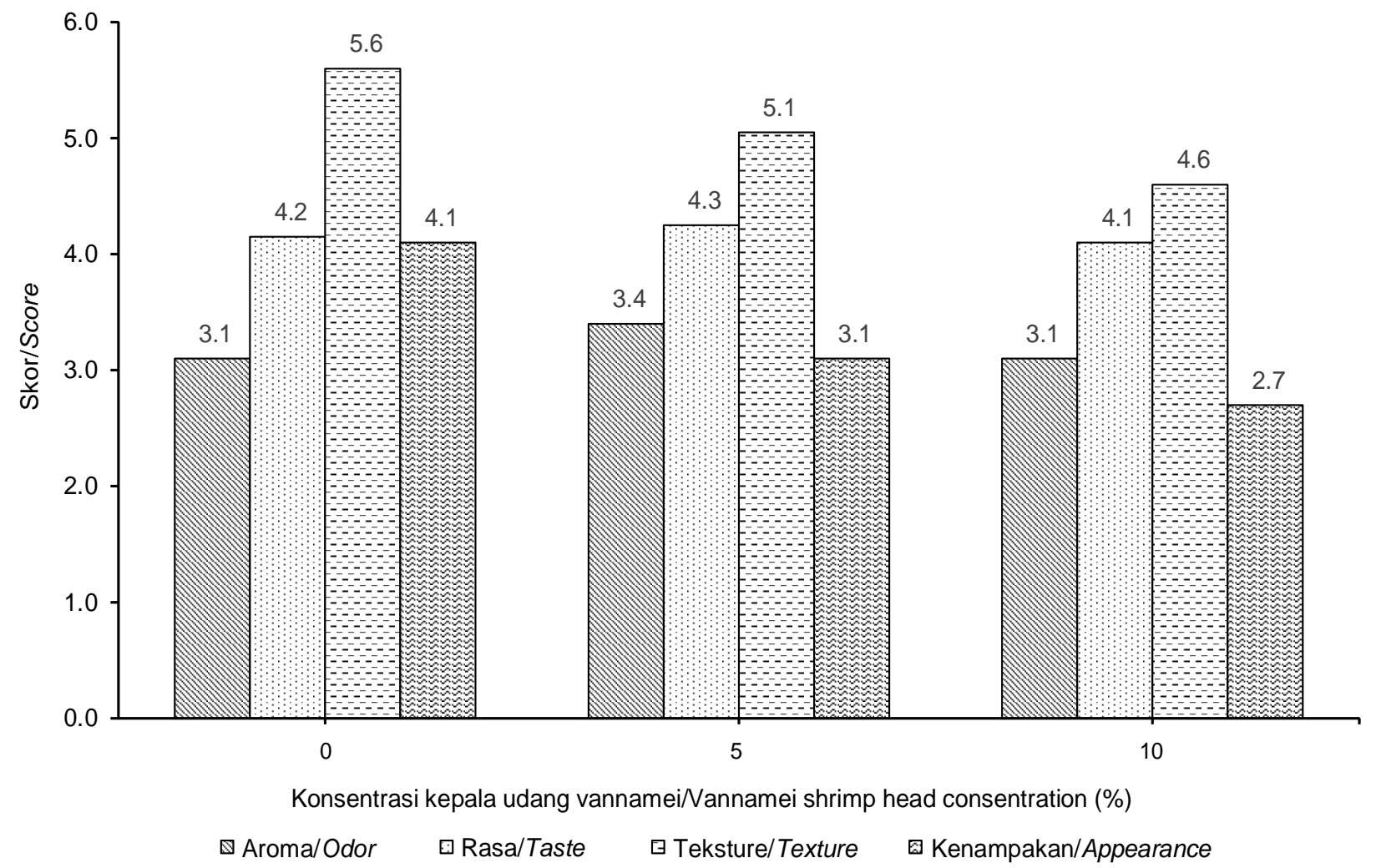

Gambar 1. Nilai analisis sensori mutu hedonik makanan ringan ekstrudat dengan penambahan kepala udang vannamei.

Figure 1. Sensory score for hedonic test of extruded snacks with the addition of vannamei shrimp head 


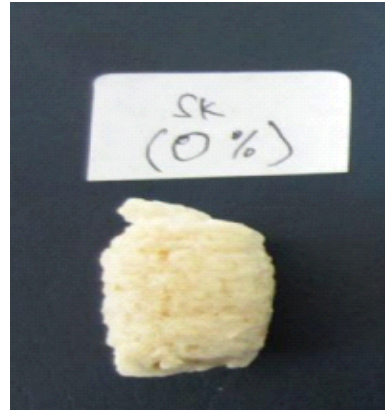

(a)

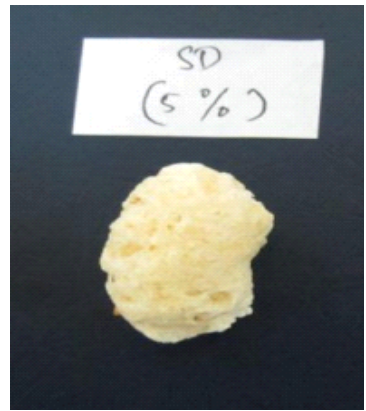

(b)

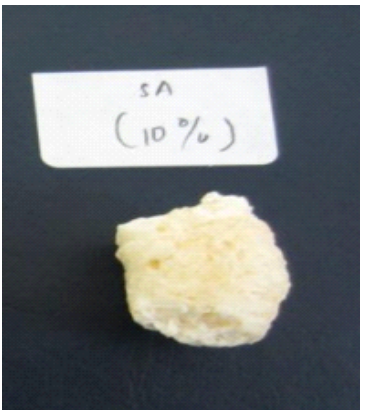

(c)

Gambar 2. Makanan ringan ekstrudat (snack) dengan penambahan kepala udang Vannamei (a) $0 \%$ (kontrol), (b) $5 \%$ dan (c) $10 \%$.

Figure 2. Extruded snacks with the addition of vannamei shrimp head (a) $0 \%$ (control), (b) $5 \%$ and (c) $10 \%$.

memicu terjadinya reaksi Maillard yang diawali dengan adanya reaksi antara grup karbonil dari gula pereduksi dan grup amino dari molekul protein membentuk basa schiff yang tidak stabil dan selanjutnya menghasilkan warna coklat atau gelap (Etxabide, Urdanpilleta, Guerrero, \& de-la Caba, 2015).

\section{Derajat Putih}

Warna makanan ringan ekstrudat merupakan salah satu parameter mutu penting dalam penerimaan konsumen. Pada Gambar 3 diketahui bahwa warna yang ditunjukkan berdasarkan nilai derajat putih makanan ringan ekstrudat tanpa dan dengan penambahan kepala udang vannamei menunjukkan tingkat kecerahan warna produk yang dihasilkan. Makanan ringan ekstrudat dengan penambahan kepala udang 0\% (kontrol), 5\% dan 10\% memiliki karakteristik warna krem kekuningan hingga kuning kecoklatan (Gambar 2). Hal ini dipengaruhi oleh bahan baku yang digunakan.

Makin tinggi konsentrasi penambahan kepala udang vannamei yang digunakan pada makanan ringan ekstrudat, maka nilai derajat putihnya semakin rendah yang diindikasikan dengan adanya kecenderngan warna gelap. Makanan ringan ekstrudat dengan penambahan kepala udang vannamei pada konsentrasi tinggi (10\%) memiliki nilai derajat putih paling rendah dibandingkan dengan konsentrasi $5 \%$ dan $0 \%$. Konsentrasi protein yang tinggi akan menghasilkan warna yang lebih gelap. Perubahan warna menjadi makin gelap yang diketahui dari makin rendahnya nilai derajat putih menunjukkan terjadinya reaksi Maillard selama proses pemasakan ekstrusi. Pada proses pemasakan ekstrusi pada suhu tinggi $\left( \pm 160^{\circ} \mathrm{C}\right)$, kandungan gula pereduksi dari molekul pati yang terdegradasi dan asam amino bebas dari molekul

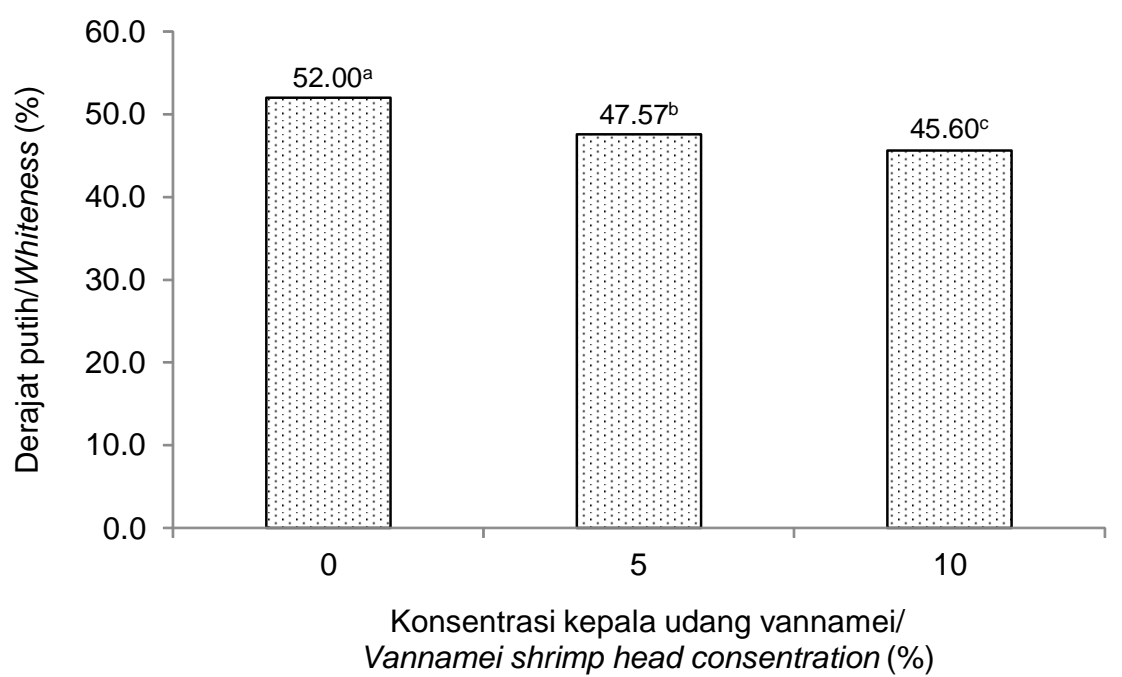

Gambar 3. Derajat putih makanan ringan ekstrudat dengan penambahan kepala udang vannamei

Figure 3. Whiteness of extruded snacks with the addition of vannamei shrimp head 
protein yang terhidrolisis merupakan prekursor utama terjadinya reaksi Maillard yang menghasilkan warna kecoklatan atau gelap. Reaksi Maillard terjadi melalui pembentukan konjugasi protein-gula di antara grup karbonil dari molekul karbohidrat pati pereduksi dengan grup amino bebas dari asam amino lisin yang dapat memicu pembentukan basa schiff, yang selanjutnya membentuk komponen amadori yang dapat menghasilkan warna gelap dengan terbentuknya melanoidin (Etxabide et. al., 2015; Guerrero, Beatty, Kerry, \& de la Caba 2012). Kandungan asam amino lisin dalam kepala udang yang cukup besar yaitu 7,79\% (Coward-Kelly et.al., 2006) menyebabkan reaksi Maillard mudah terjadi dalam proses pemasakan ekstrusi dengan penambahan kepala udang vannamei pada konsentrasi yang tinggi.

\section{Tekstur Kekerasan}

Gambar 4 menunjukkan sifat tekstur kekerasan produk makanan ringan ekstrudat tanpa dan dengan penambahan kepala udang vannamei yang diketahui dari besarnya nilai gaya (force). Kemampuan gaya (force) memecah maksimum suatu produk makanan dinyatakan sebagai ukuran kekerasan. Nilai kekerasan dari suatu produk makanan ringan ekstrudat dapat menunjukkan parameter fisik kerenyahan (crispness) (Saeleaw et. al., 2012). Salah satu parameter untuk mengukur kerenyahan suatu produk ekstrudat adalah dengan mengetahui nilai puncak pecah tekstur akibat adanya gaya (force) yang menekan (compress) (Hecke, Allaf, \& Bouvier, 1995).

Kurva kemampuan gaya (force) terhadap waktu (Gambar 4) menunjukkan seberapa besar gaya yang
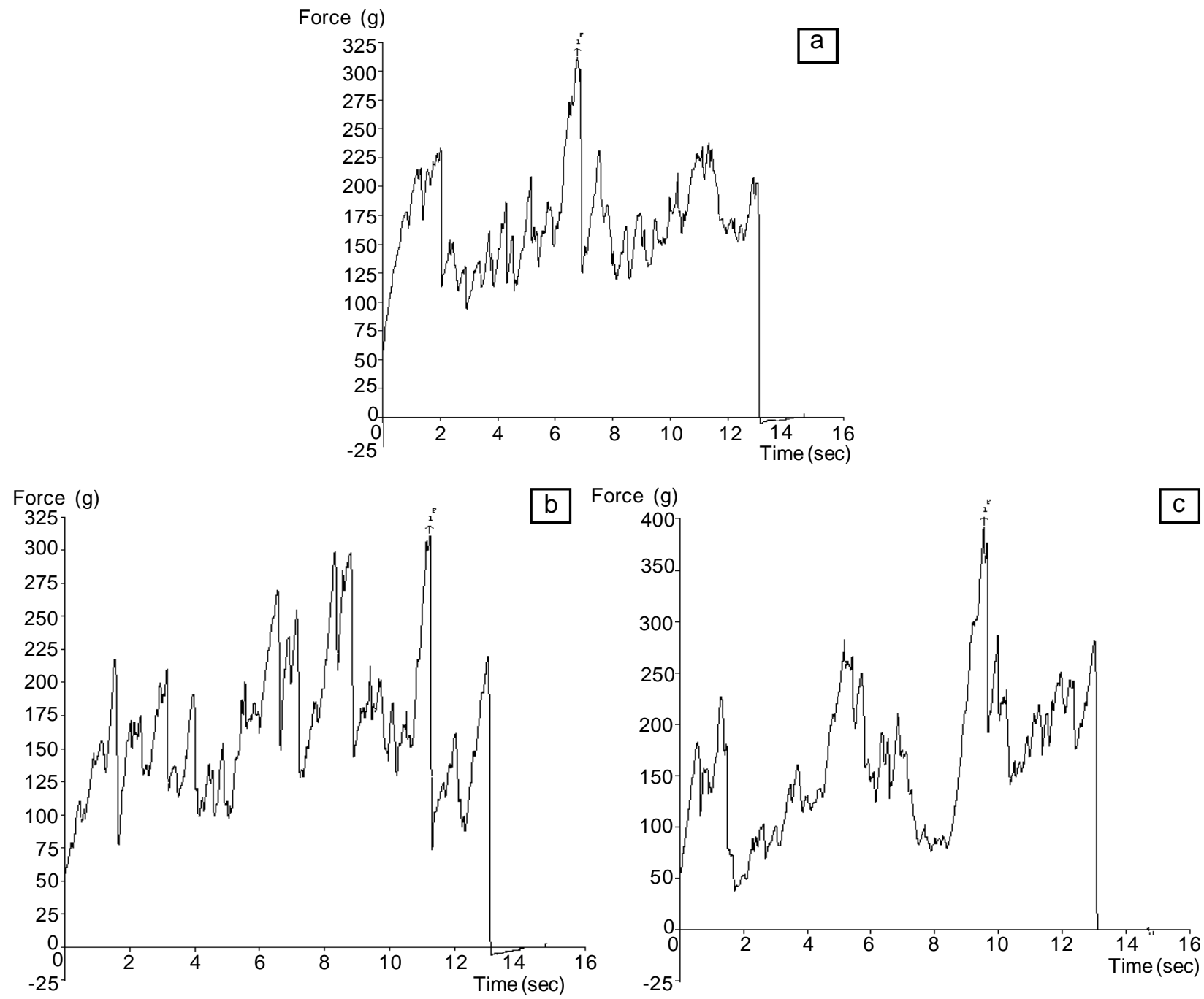

Gambar 4. Gaya memecah makanan ringan ekstrudat kontrol (a), dengan penambahan kepala udang vannamei $5 \%$ (b) dan $10 \%$ (c)

Figure 4. Force to break of extruded snacks control (a) with the addition of vannamei shrimp head $5 \%$ (b) and $10 \%(c)$. 
dibutuhkan untuk memecah dinding sel mikrostruktur makanan ringan ekstrudat dalam waktu tertentu. Produk makanan ringan ekstrudat dengan kandungan air dan protein yang lebih besar memiliki kemampuan gaya untuk memecah dinding mikrostruktur produk ekstrudat lebih besar (Day \& Swanson, 2013). Dari Gambar 4 diketahui besarnya gaya (force) memecah produk ekstrudat dengan penambahan kepala udang vannamei berbeda nyata pada konsentrasi yang berbeda maupun kontrol $(p<0,05)$. Pada konsentrasi $5 \%$ kepala udang vannamei memiliki gaya (force) memecah sebesar $324,13 \mathrm{~g}$ dalam waktu 10,67 detik. Nilai tersebut lebih rendah daripada konsentrasi $10 \%$ sebesar 408,33 g dalam waktu 11,00 detik, namun lebih besar dari kontrol sebesar $306,7 \mathrm{~g}$ dalam waktu 6,7 detik. Nilai gaya (force) makanan ringan ekstrudat dengan penambahan kepala udang vannamei (Gambar 4) lebih rendah dari pada makanan ringan ekstrudat dengan penambahan tepung daging-tulang leher ayam pedaging pada konsentrasi berkisar antara 10-30\% sebesar 741,94-1293,06 g (Islamiyah, 2009).

Karakteristik kurva gaya (force) memecah sangat dipengaruhi oleh sifat fisik dan struktur dinding sel makanan ringan ekstrudat yang dihasilkan. Selama proses pemasakan ekstrusi, struktur molekul protein akan berubah menjadi unfolded karena telah terjadi hidrolisis dan denaturasi sehingga dapat membentuk ikatan silang dengan molekul pati hingga menghasilkan suatu bentuk matriks amilosa-protein yang kompleks. Pada suhu $158-170^{\circ} \mathrm{C}$, rantai molekul amilosa dari pati dapat berinteraksi kovalen dengan molekul protein hingga menghasilkan suatu polimer yang dapat menurunkan WHC (water holding capacity). Pembentukan molekul amilosa-pati yang komplek menghambat terjadinya degradasi molekul pati (Day \& Swanson, 2013). Perubahan struktur molekul dari interaksi protein-pati makin meningkat dengan adanya kandungan protein yang tinggi dan berpengaruh pada pengembangan tekstur produk makanan ringan ekstrudat. Kandungan protein yang tinggi berpengaruh pada distribusi air pada dinding sel mikrostruktur makanan ringan ekstrudat karena molekul air terperangkap dalam matrik molekul komplek proteinpati. Hal ini dapat menyebabkan pengembangan tekstur menjadi berkurang dan struktur pori - pori sel menjadi berukuran rendah dan padat (Philip, Oey, Silcock, Beck, \& Buckow, 2017) sehingga menghasilkan tekstur makanan ringan ekstrudat yang keras.

\section{Aktifitas Air $\left(\mathrm{a}_{\mathrm{w}}\right)$}

Aktivitas air $\left(\mathrm{a}_{\mathrm{w}}\right)$ merupakan jumlah air bebas yang dapat berpengaruh pada pertumbuhan mikrobiologi yang dapat menurunkan mutu produk pangan. Nilai aktivitas air $\left(a_{w}\right)$ makanan ringan ekstrudat dengan penambahan kepala udang dapat dilihat pada Tabel 4. Diketahui bahwa penambahan kepala udang vannamei dalam konsentrasi yang besar pada proses pemasakan dengan ekstrusi menyebabkan nilai $a_{w}$ menurun. Makanan ringan ekstrudat dengan penambahan kepala udang pada konsentrasi $5 \%$ dan kontrol memiliki a ${ }_{w}$ sebesar 0,37 lebih besar daripada konsentrasi $10 \%$ sebesar $0,29(p<0,05)$. Nilai $a_{w}$ makanan ringan ekstrudat dengan penambahan kepala udang (Tabel 4) masih dalam batas yang aman terhindar dari pertumbuhan mikroba. Suatu bahan pangan dengan nilai aktivitas air $\left(a_{w}\right)$ tinggi cenderung akan lebih mudah menjadi media pertumbuhan bagi mikroba. Bakteri dapat tumbuh pada nilai $a_{w} \geq 0,75$, mikroba yang bersifat patogen dan pembusuk pada $a_{w}>0,95$, sedangkan pada $a_{w}<0,62$ mikroba tidak dapat tumbuh (Roos, 2001).

\section{Karakteristik Mikrobiologi}

Karakteristik mikrobiologi makanan ringan ekstrudat dengan penambahan kepala udang vannamei disajikan pada Tabel 5. Pada Tabel 5 diketahui kandungan E. coli pada semua sampel makanan ringan ekstrudat adalah negatif dan nilai ALT (angka lempeng total) cenderung meningkat dengan

Tabel 4 . Aktivitas air $\left(\mathrm{a}_{\mathrm{w}}\right)$ makanan ringan ekstrudat dengan penambahan kepala udang vannamei Table 4. Water activity $\left(a_{w}\right)$ of extruded snacks with the addition of vannamei shrimp head

\begin{tabular}{cc}
\hline $\begin{array}{c}\text { Penambahan kepala udang vannamei/ } \\
\text { Addition of vannamei shrimp head (\%) }\end{array}$ & $\mathbf{a}_{\mathrm{w}}$ \\
\hline 0 & $0.37 \pm 0.00^{\mathrm{a}}$ \\
5 & $0.37 \pm 0.01^{\mathrm{a}}$ \\
10 & $0.29 \pm 0.01^{\mathrm{b}}$ \\
\hline
\end{tabular}

Keterangan/Note :

Hasil merupakan nilai rata-rata tiga kali ulangan/The result are average of three replicates

Huruf yang sama pada kolom yang sama menunjukkan tidak berbeda nyata/The same letters in the same column indicate no significant difference 
Tabel 5. Hasil analisis mikrobiologi makanan ringan ekstrudat dengan penambahan limbah kepala udang vannamei

Table 5. Result of microbiology analysis of extruded snacks with the addition of vannamei shrimp head.

\begin{tabular}{ccc}
\hline Penambahan kepala udang vannamei/ & \multicolumn{2}{c}{ Parameter/Parameter } \\
\cline { 2 - 3 } Addition of vannamei shrimp head (\%) & E. coli & ALT (koloni/g)/TPC (colony/g) \\
\hline 0 & Negatif/Negative & $2.7 \times 10^{3}$ \\
5 & Negatif/Negative & $<7.1 \times 10^{3}$ \\
10 & Negatif/Negative & $5.1 \times 10^{3}$ \\
\hline
\end{tabular}

adanya penambahan kepala udang vannamei. Nilai ALT (angka lempeng total) terendah pada sampel kontrol sebesar $2,7 \times 10^{3} \mathrm{koloni} / \mathrm{g}$ dan tertinggi pada sampel dengan penambahan kepala udang vannamei $5 \%$ sebesar $<7 \times 10^{3} \mathrm{koloni} / \mathrm{g}$. Namun demikian, nilai ALT dan kandungan $E$. coli yang negatif dalam makanan ringan ekstrudat dengan penambahan kepala udang vannamei pada konsentrasi 5\% dan 10\% serta kontrol masih memenuhi persyaratan makanan ringan ekstrudat SNI 2886 tahun 2015 yang menyebutkan nilai maksimum ALT sebesar $1,0 \times 10^{4}$ koloni/g dan E.coli negatif.

\section{KESIMPULAN}

Penambahan kepala udang vannamei (Litopenaeus vannamei) dalam pengolahan makanan ringan ekstrudat dapat meningkatkan nilai gizi protein dan flavor atau aroma udang. Penambahan 5\% kepala udang vannamei dapat menghasilkan makanan ringan ekstrudat dengan kandungan protein sebesar $11,48 \%$, lemak $0,83 \%$ dengan nilai sensori tertinggi terhadap mutu aroma dan rasa, sedangkan tekstur dan kenampakan tertinggi pada sampel kontrol. Demikian pula dengan sifat tekstur kekerasan dan derajat putih makanan ringan ekstrudat tertinggi pada sampel kontrol. Selain itu semua sampel makanan ringan ekstrudat memiliki nilai aktivitas air $\left(a_{w}\right)<0,62 \%$ serta kandungan angka lempeng total $<1,0 \times 10^{4} \mathrm{koloni} / \mathrm{g}$ dan E.colinegatif. Hal ini menunjukkan bahwa makanan ringan ekstrudat dengan penambahan kepala udang $5 \%$ dapat diterima panelis dan memenuhi persyaratan makanan ringan ekstrudat berdasarkan SNI 28862015.

\section{DAFTAR PUSTAKA}

Badan Standardisasi Nasional (BSN). (2006). Penentuan kadar abu (SNI 01-2354.1-2006). Jakarta.

Badan Standardisasi Nasional (BSN). (2006). Penentuan kadar air (SNI 01-2354.2-2006). Jakarta.

Badan Standardisasi Nasional (BSN). (2006). Penentuan kadar lemak (SNI 01-2354.3-2006). Jakarta.
Badan Standardisasi Nasional (BSN). (2006). Penentuan kadar protein (SNI 01-2354.4-2006). Jakarta.

Badan Standardisasi Nasional (BSN). (2006). Cara Uji Mikrobiologi-Bagian 3: Penentuan Angka Lempeng Total (ALT) Pada Produk Perikanan (SNI 01-2332.32006). Jakarta.

Badan Standardisasi Nasional (BSN). (2006). Cara Uji Mikrobiologi- Bagian 1: Penentuan Coliform dan Escherichia coli pada produk perikanan. (SNI 012332.1-2006). Jakarta.

Badan Standardisasi Nasional (BSN). (2011). Pedoman pengujian organoleptik dan atau sensori pada produk perikanan (SNI 2346-2011) Jakarta.

Badan Standardisasi Nasional (BSN). (2015). SNI 28862015 tentang Makanan Ringan Ekstrudat. BSN. Jakarta.

Cao, W., Tan, C., Zhan X., Li, H., \& Zhang, C. (2014). Analytical Methods. Ultraviolet irradiation and gradient temperature assisted autolysis for protein recovery from shrimp head waste. Food Chemistry, 164,136141.

Coward-Kelly, G., Agbogbo, F. K. \& Holtzapple, M. T. (2006). Lime treatment of shrimp head waste for the generation of highly digestible animal feed. Bioresource Technology, 97, 1515-1520.

Day, \& Swanson. (2013). Functionality of Protein - Fortiûed Extrudeds. Comprehensive Reviews in Food Science and Food Safety, 12.

Etxabide, A., Urdanpilleta, M., Guerrero, P., dan de-la Caba.(2015). Effects of cross-linking in nanostructure and physicochemical properties of fish gelatins for bio-applications. Reactive and Functional Polymers, 94, 55-62.

Fellow, P. (2000). Extrusion. In Food Processing and Technology; Principles and Practice. Second Edition. Published in North and South America by CRC Press LC.

Guerrero, P., Beatty, E., Kerry, J. P. K., \& de la Caba. (2012). Extrusion of soy protein with gelatin and sugars at low moisture content. Journal of Food Engineering, 110, 53-59.

Hecke, E. V., Allaf, K. \& Bouvier, J. M. (1995). Texture and Structure of Crispy Puffed-Food Product I : Mechanical Properties in Bending. Journal of Texture Studies, 26, 11-15. 
Islamiyah, S. S. (2009). Sifat Fisik dan Sensori Snack Ekstrusi dengan Penambahan Tepung Daging Tulang Leher Ayam Berdaging (TDTLA). Skripsi. Fakultas Peternakan. Institut Pertanian Bogor.

Kim, H. Y., Jane, J. I., \& Lamsal, B. (2017). Hydroxypropylation improves film properties of high amylose corn starch. Industrial Crops and Products, 95 (2017), 175-183.

Matz, S. A. (1997). Snack Food Technology. Westport. Connecticut: AVI publishing Com. Inc.

Maskan, M. \& Altan, A. (2012). Advances in Food Extrusion Technology. CRC Press. Taylor \& Francis Group, LLC.

Octavia, D. A. (2007). Kajian SNI 01-2886-2000 Makanan Ringan Ekstrudat. Jurnal Standardisasi, 9 (1), 1-9.

Palupi, R. (2007). Pengaruh Pengolahan Limbah Udang Terhadap Nilai Gizi dan Daya Cerna Proteinnya. Skripsi. Universitas Sriwijaya. Palembang.

Philip, C., Oey, I., Silcock, P., Beck, J. M., \& Buckow, P. (2017). Impact of protein content on physical and microstructural properties of extruded rice starch-pea protein snacks. Journal of Food Engineering, 212, 165-173.

Roos, Y. H. (2001). Water activity and Plasticization. In Food Shelf Life Stability. Eskin, M. N.A. and Robinson, D.S. CRC Press Boca Ration London New York Washington DC.

Saeleaw, M., Dürrschmid, K., \& Schleining. G. (2012). The effect of extrusion conditions on mechanicalsound and sensory evaluation of rye expanded snack. Journal of Food Engineering, 110, 532-540.

Shaviklo, G. R., Olafsdottir, A., Sveinsdottir, K., Thorkelsson, G., dan Rafipour, F. (2011). Quality characteristics and consumer acceptance of a high fish protein puffed corn-fish snack. J. Food Sci. Technol., 48(6), 668-676. DOI 10.1007/s13197-0100191-1.

Shaviklo, A. R., Azaribeh, M., Moradi, Y., \& Zangeneh, P. (2015). Formula optimization and storage stability of extruded puffedcorn-shrimp snacks. LWT - Food Science and Technology, 63(2015), 307-314.

Suarni, \& Widowati, S. (2016). Struktur, Komposisi, dan Nutrisi Jagung. Jagung: Teknik Produksi dan Pengembangan. Balai Besar Penelitian dan Pengembangan Pertanian. http:// balitsereal.litbang.pertanian.go.id/wp-content/ uploads/2016/11/tiganol.pdf.

Subagja, Y. (2009). Fortifikasi Ikan Patin (Pangasius sp.) pada Snack Ekstrusi. Skripsi. Fakultas Perikanan dan IImu Kelautan. Institut Pertanian Bogor.

Sudarman, A., Laksmiastuti, F., \& Sumiati. (2014). Tampilan produksi broiler yang diberi pakan yang mengandung limbah kepala udang. Prosiding Konferensi dan Seminar Nasional Teknologi Tepat Guna Tahun 2014. Pusat Pengembangan Teknologi Tepat Guna. Lembaga IImu Pengetahuan Indonesia. Jakarta.

Suryaningrum, T. D., Ikasari, D., Supriyadi., Mulya., I. \& Purnomo, A. H., (2016). Karakteristik Kerupuk Panggang Ikan Lele (Clarias gariepinus) dari Beberapa Perbandinagn Daging Ikan dan Tepung Tepioka. Jurnal Pascapanen dan Bioteknologi Kelautan dan Perikanan, 11(1), 25-40. http:// dx.doi.org/10.15578/jpbkp.v11i1.234.

Xie, F., Yu, L., Su, B., Liu, P., Wang, J., Liu, H., \& Chen, L. (2009). Rheological properties of starches with different amylose/amylopectin ratios. Journal of Cereal Science, 49, 371-377. 